VAN DE WINKEL, Aurore: Les légendes urbaines de Belgique. Waterloo: Avant-Propos, 2OI7, 3I2 p.

\title{
Les légendes urbaines de Belgique
}

Emili SAMPER PRUNERA

Universitat Rovira i Virgili, Tarragona

A tots ens han explicat històries, sovint inquietants, que començaven per «Un amic m'ha explicat que...» o que acabaven «Això li va passar a l'amic d'un conegut meu». Una de les particularitats d'aquests relats és que resulta impossible trobarne l'origen (l'amic en qüestió sempre remet a un altre amic, i així fins que se'n perd la pista). Una altra és la seva adaptabilitat: podem localitzar una història en un indret que ens resulta proper (el nostre barri o ciutat) o bé a l'altra punta del món, seguint els mateixos paràmetres narratius. Ja fa uns anys que aquest tipus de relats va captar l'atenció dels folkloristes com a matèria d'estudi, però també d'especialistes d'altres àmbits (com el cinema, la literatura o la publicitat), que els han adaptat i utilitzat segons els seus interessos. El llibre que ara ens ocupa té en compte aquestes dues vessants: es tracta d'un estudi rigorós de les llegendes urbanes tractades com a gènere folklòric però sense oblidar les ramificacions que aquestes històries tenen en altres àmbits.

L'autora, Aurore Van de Winkel, és doctora en informació i comunicació de l'Université Catholique de Louvain i col-laboradora científica de l'Institut Langage \& Communication. És membre de la International Society for Contemporary Legend Research, la societat científica especialitzada a estudiar aquest gènere folklòric, i que celebra trobades anuals. Precisament Van de Winkel va ser l'encarregada d'organitzar, amb una eficàcia i un savoir faire excel-lents, la 36a edició d'aquesta trobada (Perspectives on Contemporary Legend) celebrada a Brussel-les del 5 al 9 de juny de 20I8, a l'Institut des Hautes Études des Communications Sociales (IHECS). Van de Winkel està considerada l'especialista belga de les llegendes urbanes, tema al qual va dedicar la seva tesi així com nombrosos articles i conferències. Participa de manera regular en els mitjans de comunicació parlant d'aquest tema i també organitza per al públic en general rutes de llegendes a Brussel-les. A Les légendes urbaines de Belgique, convida el lector a descobrir les llegendes més populars que circulen avui dia a Bèlgica i que han inspirat l'obra d'escriptors de ficció com Victor Hugo, Franquin, Hergé o Willy Vandersteen. En aquest llibre, l'autora remunta a l'origen d'aquestes llegendes i en descriu l'eficàcia, el grau de veracitat així com les connexions amb els relats tradicionals.

No és el primer cop que Van de Winkel dedica una monografia a aquesta qüestió. De caire més teòric (tot i que també conté molts casos pràctics) i d'un abast més genèric i no restringit únicament a les llegendes urbanes, l'any 2012 va publicar a Edipro Gérer les rumeurs, ragots et autres bruits. En aquest treball, l'autora distingeix entre rumor i llegenda urbana. Partint de la premissa, en tots dos casos, que «il n'existe pas de consensus sur sa définition car la réalité qu'il recouvre est complexe» (p. I7), parla de la connotació negativa del terme rumor que «désigne à la fois des processus de propagation de messages, circulant massivement sans être contrôlés, et leur contenu» (p. I7). Quant a la llegenda urbana, Van de Winkel adverteix que, a França, els autors utilitzen sovint com a sinònims els dos termes 
(rumor i llegenda urbana). Sobre aquesta qüestió terminològica, resulta aclaridor recordar el que Josep M. Pujol explica: «n'hi ha que proposen distingir entre "rumors" (simples enunciats temàtics sense protagonistes concrets ni estructura narrativa, matrius de relat més que no pas relats autèntics) i "llegendes urbanes" (que serien autèntics relats, amb protagonistes concrets)». ${ }^{\mathrm{I}}$

La definició que proposa Van de Winkel és que ens trobem davant d'«un récit court qui relate des événements —-souvent connotés négativement et provoquant le dégoût, la peur ou la surprise - arrivés à un individu au sein de notre société contemporaine»(p. 27). Com dèiem més amunt, l'autora caracteritza aquest gènere dient que el relat s'atribueix a algú (tot i que és anònim) i que travessa continents i períodes de temps tot adaptant-se a les preocupacions, les característiques o les especificitats d'aquell qui l'explica. Van de Winkel proposa en aquest treball una classificació de llegendes urbanes formada per: llegendes d'advertència, llegendes moralitzants, llegendes de venjança, llegendes de misteri i llegendes cíniques.

Efectivament, la qüestió terminològica al voltant de les llegendes urbanes no està resolta i les denominacions atribuïdes a aquest tipus de relat són diverses: llegendes urbanes, llegendes metropolitanes, llegendes contemporànies, rumors, anècdotes apòcrifes, mites moderns, històries creïbles, històries llegendàries d'avui o llegendes repulsives, per citar-ne les més conegudes. En qualsevol cas, reprenent les paraules de Josep M. Pujol de la cita anterior, «tant se val: són etiquetes atribuïdes pels folkloristes, que més que delimitar un "gènere" del folklore narratiu remeten a altres tantes etapes de la investigació i il·lustren més sobre els folkloristes i la història de la recerca que no pas sobre el mateix folklore».

Si ens centrem, ara sí, en Les légendes urbaines de Belgique, hi trobem una nova definició. Per Van de Winkel, les llegendes urbanes

sont généralement attribués à une source fiable (un membre de la famille, de la police, d'un hôpital, d'une institution, etc.) et proche de ceux qui les relatent, ce qui leur donne crédibilité et impression de proximité. Or ils existent depuis de nombreuses années et ont souvent été créés dans un autre pays, voire un autre continent, et sont arrivés jusqu'à nous grâce au bouche-à-oreille, aux conversations téléphoniques, ou encore via les tracts, les blogs, les forums, les réseaux sociaux et même la presse [p. I6].

Aquest darrer punt relatiu a la transmissió dels relats és important. Tot i que avui dia encara se'n poden trobar versions que circulen oralment (de boca a orella), la seva difusió mitjançant la premsa i, sobretot, les xarxes socials, és més habitual.

El llibre se centra en les llegendes urbanes, tot i que també s'hi troben referències a relats que podríem considerar «llegendes tradicionals». L'autora matisa les diferències entre aquests dos tipus de llegendes: «Contrairement aux récits légendaires traditionnels, les légendes urbaines ne concernent pas une personnalité ou un fait historique ancien mais racontent plutôt un événement inattendu qui se serait glissé récemment dans le quotidien d'un citoyen lambda. Elles sont présen-

I «Reflexions sobre el folklore a propòsit dels rumors», publicat l'any 2002 dins del recull «Benvingut/da al club de la sida» $i$ altres rumors d'actualitat del Grup de Recerca Folklòrica d'Osona, i inclòs dins Això era i no era. Obra folklòrica de Josep M. Pujol. Tarragona: Publicacions URV, 2OI3, p. 35I. 
tées comme authentiques» (p. I4). Tot i això, com ella mateixa explica, s'observa una relació estreta entre les llegendes urbanes i les tradicionals, ja que hi ha un canvi en els elements que formen part de les llegendes tradicionals (com ara fantasmes o el diable), que són substituïts per elements moderns. El motiu narratiu s'adapta segons el públic al qual s'adreça el relat i al seu context de difusió, i totes dues tenen un caràcter exemplar (p. I7). En aquest sentit, cal recórrer de nou a Josep M. Pujol, que ens recorda que la distinció entre les velles i les noves llegendes no respon al contingut, atès que «la majoria dels rumors que presentem tenen els seus equivalents escampats arreu del món i no semblen tenir un comportament diferent de les velles llegendes recollides pels folkloristes del segle XIX». ${ }^{2}$

Amb relació a la difusió de les llegendes, Van de Winkel introdueix el concepte de «belgicisation» per caracteritzar l'adaptació d'aquests relats, en aquest cas concret, a la cultura belga: «Parce que cette histoire vos a touchés, interpellés, impliqués; que sa véracité était probable ou que sa morale se révélait à vos yeux plus importante que son authenticité. Elle vous permettait de parles de vous, de votre groupe, de vos valeurs, de vos interdits et même de prouver votre solidarité avec vos proches!» (p. I7). Aquesta proposta resulta interessant i exemplifica perfectament la capacitat d'adaptació i, alhora, d'identificació d'aquests relats. Així, un mateix relat adapta alguns dels detalls concrets a la societat (i cultura) on s'explica, fet que repercuteix, al mateix temps, en la versemblança. Aquesta mateixa adaptació facilita la identificació amb els receptors (i emissors) del relat, ja que aquest no fa més que donar llum a les preocupacions i pors d'aquest col-lectiu.

El llibre està profusament il.lustrat amb imatges i fotografies a tot color que exemplifiquen les versions de les llegendes que s'hi presenten. La maquetació també en facilita la lectura, amb l'ús de colors en els capítols i les seccions. Tal com adverteix l'autora a l'inici del llibre (p. 8), els textos reproduïts dels missatges originals que mostren versions concretes de les llegendes es presenten com s'han recollit i difós, és a dir, amb faltes d'ortografia i gramàtica incloses. Per distingir-los de la resta del text, es presenten dins d'un quadre del mateix color utilitzat en aquell capítol.

Van de Winkel divideix el llibre en set capítols diferents, organitzats temàticament, i que inclouen diferents subseccions. Els capítols són els següents:

\section{Aliments sospitosos.}

En aquest primer capítol s'exposen i analitzen les llegendes urbanes relacionades amb el menjar partint inicialment de la contraposició entre el menjar tradicional i el menjar industrial i el paper amenaçador d'aquest segon. Els exemples mostrats són diversos: des de l'anomenat carrer de les Pites (amb establiments que ofereixen menjar que conté sis tipus d'esperma diferents) fins a la lasanya Findus elaborada a partir d'anus de porcs. L'autora presenta versions del món francòfon, més escampades geogràficament, així com les que se circumscriuen només a Bèlgica, i destaca la gran influència americana present a les llegendes urbanes escampades per Europa (p. 6o). També hi són presents els exemples procedents del cinema, la literatura o el còmic, amb una aparició destacada, en aquest darrer

2 «Reflexions sobre el folklore a propòsit dels rumors», publicat l'any 2002 dins del recull «Benvingut/da al club de la sida» $i$ altres rumors d'actualitat del Grup de Recerca Folklòrica d'Osona, i inclòs dins Això era i no era. Obra folklòrica de Josep M. Pujol. Tarragona: Publicacions URV, 2OI3, p. 343. 
cas, del personatge de Tintín. Van de Winkel utilitza en aquest capítol el concepte de «néophobie» (p. 24), referit a la por davant dels productes nous, que pren del treball De source sûre. Nouvelles rumeurs d'aujourd'hui, publicat el 2005 per Véronique Campion-Vincent i Jean-Bruno Renard, dos especialistes d'aquest àmbit en el món francòfon. També s'inclouen en aquest capítol les llegendes relacionades amb les begudes (Cokelore, p. 50) i les de les drogues repartides a les portes de les escoles. En aquest darrer cas, l'autora en destaca l'adaptabilitat i com les variants mostren la gran capacitat d'adaptació de la nostra por (p. 73).

II. Dones, aneu amb compte.

El segon capítol està dedicat als perills que afecten una part concreta de la nostra societat, com són les dones. L'autora enceta aquesta temàtica amb l'estudi de les llegendes sobre segrestos produïts als emprovadors de determinats comerços i inclou fotografies dels carrers de Brussel-les (i de Bèlgica) on se situen aquestes llegendes (p. 78-8o). És inevitable, si es parla d'aquest tema, la referència al cas d'Orleans (un dels més coneguts i estudiats) i a les versions que s'expliquen per tot el territori francès. ${ }^{3}$ A Brussel-les, en concret, se situa l'anomenat «Belgian Traffic»: el tràfic de joves verges menors de nacionalitat anglesa. Per il-lustrar-lo, Van de Winkel inclou exemples procedents de novel-les i còmics (p. 84-88). El rerefons d'aquesta llegenda no és altre que la modernització de les llegendes tradicionals amb l'aparició de l'emancipació de les dones (p. 89).

A banda de l'emprovador, un altre espai perillós per a les dones és el lavabo. En aquest cas, l'aparició d'acudits sobre el tema és paral·lel al de les llegendes (p. 94-95). Un tòpic recurrent en les llegendes que afecten les dones és la relació que s'estableix entre elles i els perfums. En aquests casos, el rumor només les afecta a elles (p. 98), en un clar exemple de prejudici per raó de sexe i de perpetuació d'estereotips. Totes aquestes llegendes presenten un grau d'adaptació diferent segons el país on s'expliquen (p. 99). Altres temes presents en aquest capítol són l'esterilització de les víctimes, drogades contra la seva voluntat, que es contraposa amb la realitat, ja que la droga que apareix en aquestes històries no té aquests efectes en la vida real (p. Io3); la referència a llegendes presents en l'arquitectura de Brusselles, com els penis esculpits per part dels agressors en determinats indrets (p. IO3); l'anomenat somriure de l'àngel, una agressió present també a la literatura, al cinema i a la televisió, amb el conegut exemple del personatge del Joker (p. Io6-Io8); l'exemple de l'autoestopista de les mans peludes, amb una versió a Perpinyà inclosa (p. II2); el transvestisme d'un personatge tan conegut en la literatura popular com és la Caputxeta, o l'anunci de Toyota Corolla, de 2009, com a mostra de la presència de les llegendes urbanes en espots comercials (p. II3) per la seva potència visual i per la complicitat que troba en l'espectador, que reconeix el referent.

3 Sobre aquest mateix tema però analitzant versions catalanes, i tenint en compte, això sí, l'àmbit internacional (el citat cas del rumor d'Orleans, entre d'altres), es pot veure el treball «De les històries extraordinàries als rumors: el tràfic de blanques com a exemple de folklore contemporani» publicat al volum 9 de la revista eHumanista/IVITRA (juny de 20I6): II6-I35, disponible en línia a <http://www.ehumanista.ucsb.edu/sites/secure.lsit.ucsb.edu.span. d7_eh/files/sitefiles/ivitra/volume9/7.Samper_o.pdf> [data de consulta: octubre de 20I8]. 
III. Animals molestos.

Un dels trets remarcables d'aquest llibre és que, per a cada llegenda, s'explica el tema de rerefons i no només l'argument de la història. Això ho trobem, en aquest capítol dedicat als animals, amb l'exemple de la iuca peluda. L'autora recorre a una autoritat en el tema, com és Rolf Wilhem Klintberg, per assenyalar el simbolisme sexual present en aquesta llegenda (p. I24). ${ }^{4}$ Altres exemples d'aquest aprofundiment en el rerefons de les llegendes els trobem en la coneguda història dels cocodrils a les clavegueres i la simbologia d'aquests animals (p. I32-I34) o amb l'expressió del racisme mitjançant la història del ruc del parc Josaphat (p. I36-I39). Altres històries curioses incloses per l'autora en aquest capítol són les anomenades «cartes de la nevera», que inclouen factures de països llunyans que contenen sorpreses (desmentides científicament) (p. I25), o el bonsai gat, una història difosa per correu electrònic i que té precedents datats al segle XIX i versions en còmic (p. I42).

IV. Vigileu els vostres fills.

Un altre perill real que apareix representat a les llegendes urbanes és el que afecta els més petits de casa. Aquest quart capítol inclou exemples actuals, com els dels segrestos de nens que tenen lloc en coneguts centres comercials com Ikea (p. I46). L'autora ressegueix els precedents antisemites de la història (p. I5I) i n'assenyala la relació amb la figura del vampir (p. I53-I54). Les converses cara a cara ja no són, actualment, l'únic escenari en el qual es difonen aquestes històries. Xarxes socials com Facebook i Twitter serveixen d'aparador i de replicador, gairebé diari en alguns casos, de llegendes urbanes. Amb relació al tema d'aquest capítol, destaquen dues històries que han trobat a Facebook el lloc on desenvolupar-se. D'una banda, els clàssics episodis que relacionen les calcomanies repartides a les portes dels centres escolars amb les drogues i, més recentment, la presència de ganivets als tobogans dels parcs infantils. Són episodis que provoquen una gran indignació dels pares a xarxes com Facebook (p. I63). D'altra banda, cal esmentar l'aparició dels pallassos hostils, produïda a França el mes d'octubre de 20I4, i que va provocar la creació de brigades antipallassos a Facebook. L'autora ressegueix, en aquest cas, els antecedents americans, així com les versions televisives (p. I67).

\section{Ningú se salva.}

Un altre tema recurrent en aquestes històries és el de robatori d'òrgans. El cas més conegut és el del robatori de ronyons, però no és pas l'únic. Van de Winkel es fa ressò de les variants internacionals d'aquesta llegenda i fa notar com la identitat de l'agressor varia segons on se situa la versió (p. I74-I75). També contraposa aquest fet amb la realitat dels transplantaments, que demanen unes condicions molt estrictes i específiques per poder-se dur a terme amb èxit (p. I77). No hi falten els referents procedents de sèries de televisió (p. I80), però cal destacar que aquests apareixen explicats en aquest capítol juntament amb rumors que tenen poc de cinematogràfics, com són els rumors de la Primera Guerra Mundial que

\footnotetext{
4 Klintberg és un especialista des de l'àmbit germànic, i ha publicat diversos treballs sobre llegendes urbanes. En català és de referència obligada l'article «L'aranya a la iuca. Llegendes urbanes d'avui», publicat al número 4 de la Revista d'Etnologia de Catalunya (febrer de 1994): 32-43, dins del dossier «Etnopoètica: el folklore, de bella art a art aplicada», coordinat per Josep M. Pujol.
} 
expliquen com es tallaven les mans als infants. En aquest exemple concret, l'autora assenyala l'ús emocional que tenia aquest rumor, utilitzat en contra dels alemanys, dins del context d'introducció de les pràctiques colonials a Europa (p. I84-I87).

La venjança com a motiu i la reacció de la víctima davant d'un fet negatiu són el rerefons de la coneguda llegenda «Benvingut al club de la sida», on la sexualitat té un paper destacat. ${ }^{5}$ En aquesta ocasió, s'expliquen de manera racional les opcions reals del contagi i com aquesta llegenda es transforma segons el territori on s'explica, amb referències concretes a exemples situats a Espanya (p. I89-I93).

Dins d'aquest capítol, hi trobem també les teories del complot (per part de governs i farmacèutiques) amb les campanyes d'enverinament de la població mitjançant les vacunes que maten. Es tracta de l'anomenat efecte «gremlin» dels avenços tecnològics, concepte que l'autora pren d'un altre treball de Véronique Campion-Vincent i Jean-Bruno Renard. ${ }^{6}$ També tenen cabuda en aquest capítol les explosions de les estacions de servei provocades per l'ús de telèfons mòbils. En aquesta ocasió, Van de Winkel inclou com a exemples de la difusió de la llegenda el missatge difós per la petrolera Shell, així com les instruccions presents en mòbils de la marca Samsung i de la companyia Vodafone (p. 209-2I2).

\section{Bons plans i revenges.}

L'atemptat a les Torres Bessones de l'iı de setembre de 200 I va tenir unes conseqüències que van anar més enllà del terreny exclusivament polític i el folklore, com és obvi, no en va restar al marge. L'exemple més clar, en aquest sentit, és la llegenda de l'anomenat terrorista penedit, que apareix en un context molt concret, com és l'escenari posterior a aquest atemptat, així com la celebració de l'aniversari, deu anys més tard. Aquesta mateixa història, però amb canvis en la nacionalitat del protagonista, ja es troba en llegendes de la Primera Guerra Mundial. L'autora fins i tot recula més en el temps i assenyala la relació entre aquesta llegenda i el relat de l'hospitalitat recompensada dels germans Grimm,7 que juga amb els mateixos ressorts narratius (p. 2I6-2I8). Un cas de revenja similar a aquest el trobem dins del context del transport públic, amb l'anomenat «tiquet de revenja», que apareix com a expressió del racisme. Fins i tot hi ha un curtmetratge belga de I993 basat en aquesta llegenda (p. 22I).

En aquest mateix capítol, hi trobem exemples diversos de respostes enginyoses donades per estudiants que volen trampejar les proves acadèmiques que han de superar. Un d'ells explica com resoldre una pregunta en un examen sobre què és el coratge. La resposta de l'estudiant és deixar l'examen en blanc (p. 223-224). Van de Winkel compara aquestes històries amb altres de semblants (i anteriors cronològicament) i que, en aquest cas, no estan protagonitzades pels estudiants, sinó per un soldat i el diable.

5 Recordem que aquest és precisament el títol del recull publicat pel Grup de Recerca Folklòrica d'Osona i Josep M. Pujol l'any 2002 («Benvingut/da al club de la sida» $i$ altres rumors d'actualitat).

6 En aquest cas, es tracta del llibre Légendes urbaines. Rumeurs d'aujourd'hui, publicat a París per Payot \& Rivages l'any 2002.

7 Es tracta del tipus rondallístic $750 \mathrm{OB}$ Hospitality Rewarded segons l'índex internacional The Types of International Folktales, d'Aarne, Thompson i Uther, publicat el 2004. 
VII. Desencripteu els símbols.

El darrer capítol del llibre està dedicat a la simbologia i hi trobem símbols de tota mena, amb interpretacions també diverses. Un d'ells és el del misteri de les sabates que es troben penjades en diferents indrets d'una ciutat, i que es coneix amb noms diversos (Shoes tossing, Shoetoss, Shoe flinging). Les explicacions també són diverses: des del fet que és un ritual inventat pels marines americans quan tornen a la vida civil fins a l'explicació que es tracta d'una manera de marcar el territori per part de bandes urbanes (i la seva relació amb la droga), o justificacions de tipus artístic aparegudes en pel-lícules. L'autora fins i tot s'atreveix a realitzar ella mateixa un experiment penjant unes sabates i fent-ne un seguiment (p. 233-235).

Altres símbols són els que podem trobar a les portes de les cases, en aquest cas, posats per lladres per indicar-ne la idoneïtat per realitzar les seves accions. Aquests fets ja apareixen a Egipte i a l'Antic Testament, en aquest cas com un símbol de protecció divina i d'advertència. L'autora reprodueix exemples diversos de símbols i alfabets i n'ofereix la seva interpretació. En un context plurilingüe com el belga, per exemple, la lletra «V» té un significat diferent segons la llengua en la qual es llegeix: victoire (francès) i vrijhed (llibertat en neerlandès) (p. 236-240). Tots aquests alfabets tenen relació, com és lògic, amb l'alfabetització, però també són expressió de prejudicis racials (davant col-lectius com gitanos, romanesos, etc.) (p. 246-247). Un altre tipus de llenguatge secret és el de la publicitat i Van de Winkel recorre a exemples de la Primera Guerra Mundial amb la presència de plaques publicitàries durant la invasió de Bèlgica i França (p. 247-253).

En aquest capítol també es tracten les prediccions funestes i catastròfiques. Una de les més conegudes (i estudiades) és la de l'autoestopista fantasma, que l'autora relaciona amb l'anomenada «dama blanca». En aquestes llegendes s'hi troben referents religiosos i també de la cultura popular, com un fan fiction penjat a YouTube l'any 20I3, o la presència d'aquest personatge als còmics de Tintín. Van de Winkel repassa exemples apareguts en diferents indrets, així com la presència de la dama negra de Brussel-les, i relaciona l'episodi amb la banalització de l'automòbil que tingué lloc als anys vint als Estats Units (p. 255-26I). Altres prediccions que, en aquest cas, anuncien la fi del món es relacionen (de nou) amb l'atemptat de l'II de setembre, amb l'efecte 2000 o amb el calendari maia de 20I2. Es tracta, en definitiva, d'explicacions mítiques en una societat tecnològica (p. 264-276).

Van de Winkel tanca el llibre amb un apartat de conclusions en el qual sintetitza l'aportació d'aquest treball dins el conjunt d'estudis sobre les llegendes urbanes. Com ja s'ha vist en les pàgines precedents, aquestes històries s'adapten a cada col-lectiu en el qual apareixen. En el cas dels belgues, en destaca la identitat singular, l'imaginari col·lectiu i la mentalitat particular. La majoria de les històries són negatives i aquest fet està directament relacionat amb la seva funcionalitat. Així, quan apareixen indrets perillosos en les llegendes urbanes, s'aconsegueix que la població estigui informada, proposi solucions i mostri solidaritat. En definitiva, hi suren els problemes actuals i les nostres preocupacions i valors. També és important, com diu l'autora, destacar la instrumentalització d'aquests relats (mai no són innocents) i el fet que no importa tant la seva veracitat com el fet que la seva credibilitat ve donada per la proximitat dels informants. 
El contingut de Les légendes urbaines de Belgique és rigorós i acadèmic, però la forma en què es presenta és atractiva per a qualsevol tipus de públic. Com s'ha vist, hi ha nombrosa informació de cada llegenda i el lector interessat hi trobarà fàcilment pistes per aprofundir en cada relat. L'extensa i completa bibliografia, dividida en diferents seccions i que gairebé arriba a la trentena de pàgines, no es refereix únicament al món francobelga i és una bona mostra d'aquest fet. Com diu Van de Winkel al final del llibre, interpel-lant el lector, és a ell a qui li correspon dir si el seu paper és actiu, com a difusor de les llegendes, o més aviat passiu, com a receptor crèdul de les històries. Aquest llibre representa una bona eina si es vol optar per una tercera opció, la crítica. 